\title{
PEMETAAN PRODUK ANDALAN SEKTOR PERTANIAN DI KABUPATEN MUKOMUKO
}

\author{
Indra Cahyadinata \\ Jurusan Sosial Ekonomi Pertanian Fakultas Pertanian Universitas Bengkulu
}

\begin{abstract}
Data of PDRB Mukomuko District indicates that contribution of agricultural sector up to $50,7 \%$. That means, agricultural sector is one of the sectors able to be made as bases in development of Mukomuko. This Research aim is to cluster of agricultural product that is able to be developed as bases product and to study of feasibility of agricultural product. Research results indicate that food crop become bases in three sub-districts (Lubuk Pinang, Teras Terunjam and Pondok Suguh), animals breeding become bases in three sub-districts (Lubuk Pinang, Mukomuko Utara and Mukomuko Selatan), fishery become bases at three sub-districts (Mukomuko Utara, Mukomuko Selatan and Pondok Suguh) and plantation sub-sector become bases at all of subdistricts. Financially, all farming type can be categorized a feasible, but its business (not include palm) is small scale, so the earnings is unable to fulfill requirement of household consumption.
\end{abstract}

Keyword : agricultural sector, bases product, product mapping

\section{PENDAHULUAN}

\section{Latar Belakang}

Kabupaten Mukomuko merupakan salah satu kabupaten baru di Propinsi Bengkulu, yang dimekarkan dari Kabupaten Bengkulu Utara (sebagai kabupaten induk) pada Tahun 2003, yang secara geografis diapit oleh Samudera Hindia dan Taman Nasional Kerinci Sebelat (TNKS). Sebagai kabupaten baru hasil pemekaran, maka kabupaten ini memerlukan dasar pijakan yang kuat dalam gerak pembangunannya, terutama pembangunan perekonomian. Dasar pijakan pembangunan ekonomi yang kuat erat kaitannya dengan kemampuan memilih prioritas pembangunan secara lebih terencana dan terarah guna diperolehnya optimalisasi dalam pemanfaatan sumberdaya yang tersedia.

Secara umum, pembangunan di Kabupaten Mukomuko memiliki dua tujuan utama, yaitu (1) sebagai tuntutan ekonomi masyarakat dan (2) memperoleh dan meningkatkan pendapatan asli daerah (PAD) atau produk domestik regional bruto (PDRB). Untuk mencapai dua tujuan utama pembangunan di Mukomuko, pemerintah daerah sebagai pengambil kebijakan dihadapkan pada banyak pilihan (multi sektor). 
Pada saat ini, berbagai produk multi sektor diusahakan dan dikembangkan pada beberapa desa/daerah. Ini berarti, pengembangan produk masih berorientasi pada kuantitas produk dan agak mengesampingkan kualitas produksi. Idealnya, suatu produk dikembangkan pada suatu daerah tertentu sehingga daerah tersebut dapat menjadi pusat/sentra produksi produk yang berkualitas dan berdaya saing. Pengembangan produk pada suatu daerah mempertimbangkan spesifik lokasi (keunggulan lokal) yang dimiliki oleh daerah tersebut, sehingga produk yang dikembangkan pada setiap daerah menjadi produk andalan yang diunggulkan.

Kebijakan yang tepat tentulah merupakan suatu kebijakan yang didasarkan pada kearifan lokal. Data kependudukan menunjukkan bahwa jumlah penduduk Kabupaten Mukomuko pada Tahun 2007 sebanyak 150.477 jiwa dengan jumlah Kepala Keluarga 36.140 KK. Mata pencaharian utama penduduk adalah sebagai petani/nelayan sekitar $76,9 \%$, jasa dan perdagangan sekitar $17,3 \%$ dan lain-lain sekitar $6,8 \%$ dari jumlah penduduk yang bekerja. Data PDRB juga menunjukkan bahwa sektor pertanian (dalam arti luas) pada Tahun 2005 memiliki kontribusi sebesar 50,7\% terhadap total PDRB. (Bappeda Kabupaten Mukomuko, 2007).

Data tersebut menunjukkan bahwa sektor pertanian merupakan salah satu sektor yang dapat dijadikan sebagai andalan dalam pembangunan Kabupaten Mukomuko. Untuk mewujudkan pembangunan sektor pertanian yang terencana dan terarah, maka perlu dilakukan kajian tentang pemetaan produk andalan yang dapat dikembangkan di Kabupaten Mukomuko sesuai dengan potensi lokal pada setiap wilayah, sehingga dapat dibuat pengelompokan (cluster) wilayah berdasarkan produk andalan tersebut.

\section{Tujuan}

1. Memetakan wilayah (membuat pengelompokan wilayah) berdasarkan produk sektor pertanian yang dapat dikembangkan sebagai produk andalan di Kabupaten Mukomuko

2. Mengkaji kelayakan usaha dari produk andalan yang dapat dikembangkan berdasarkan kondisi yang ada.

\section{METODOLOGI}

\section{Data}

Cakupan data dalam studi ini dapat dikelompokkan menjadi 2 (dua) jenis, yaitu :

1. Data Sekunder, yaitu data yang diperoleh melalui review dan pengumpulan data terhadap dokumen-dokumen tertulis dan laporan-laporan kegiatan yang telah dilaksanakan serta laporan-laporan atau dokumen resma lainnya. Salah satu data sekunder yang paling penting digunakan dalam studi ini adalah data profil desa-desa yang ada di Kabupaten Mukomuko. 
2. Data primer, yaitu data yang diperoleh melalui wawancara terstruktur dengan menggunakan statu pedoman pertanyaan (kuesioner) yang telah disiapkan. Informasi yang diperoleh dari kuesioner dapat menggambarkan keragaan usaha masyarakat, seperti proses pemasaran dan kelayakan usaha.

\section{Metode Sampling}

Populasi dalam studi ini adalah seluruh desa dan kelurahan yang ada di Kabupaten Mukomuko, yang terdiri 84 desa dan 1 (satu) kelurahan. Pengambilan sampel desa untuk melihat keragaan usaha masyarakat dilakukan melalui dua tahap, yaitu :

1. Menentukan produk (barang dan jasa) yang unggul pada suatu desa/kelurahan, sesuai dengan ruang lingkup kegiatan. Pemilihan desa juga memperhatikan sebaran dari produk yang andal (unggul). Dengan demikian, desa terpilih menjadi tersebar dan merata berdasarkan keunggulan produk yang dapat dikembangkan.

2. Pada masing-masing desa terpilih sebagai sampel yang mewakili setiap sektor/sub-sektor, secara accidental sampling.

Berdasarkan tahapan tersebut, maka desa-desa yang terpilih sebagai sampel seperti disajian pada Tabel 1.

Tabel 1. Desa-Desa Terpilih sebagai sampling dan Jumlah Responden

\begin{tabular}{cllc}
\hline No & \multicolumn{1}{c}{ Desa } & \multicolumn{1}{c}{ Produk Andalan } & Jumlah Responden (orang) \\
\hline 1 & Tanah Rekah & Kelapa Sawit & 5 \\
& & Karet & 5 \\
& & Peternakan & 11 \\
2 & Pasar Sebelah & Padi & 5 \\
& & Jagung & 6 \\
3 & Lalang Luas & Padi & 10 \\
4 & Bumi Mulia & Perikanan Darat & 5 \\
5 & Pasar Mukomuko & Perikanan Laut & 10 \\
\hline & & Jumlah & 57 \\
\hline
\end{tabular}

Dengan demikian, jumlah responden berdasarkan produk subsektor aktivitas ekonomi masyarakat adalah :
1. Kelapa Sawit
: 5 orang responden
2. Karet
: 5 orang responden
3. Peternakan
: 11 orang responden, yang terdiri dari usaha: sapi 2 orang, kerbau 1 orang, kambing 2 orang, itik 3 orang, domba 1 orang, dan ayam 2 orang.
4. Padi : 15 orang responden 
5. Jagung

6. Perikanan Darat

7. Perikanan Laut
: 6 orang responden

: 5 orang responden

: 10 orang responden

\section{Teknik Analisa Data}

Secara umum, analisa data dalam kegiatan ini menggunakan analisa kualitatif dan kuantitatif, dimana semua hasil analisa disajikan secara deskriptif. Analisa kualitatif merupakan upaya penjelasan yang lebih komprehensif dan mendalam terhadap hasil wawancara melalui kuesioner dan studi literatur. Analisa kuantitaif untuk menggambarkan sesuatu yang terukur dengan jelas melalui indikator-indikator yang telah ditentukan.

Lebih spesifik, teknik analisa data yang dilakukan adalah :

\section{Penentuan Produk Andalan}

Untuk menentukan produk (barang dan jasa) andalan pada setiap desa/kelurahan digunakan model ekonomi basis (analisis pemusatan ekonomi) dengan Location Quotient (LQ). LQ merupakan metode analisa yang umum digunakan dalam ekonomi geografi. Nilai LQ merupakan suatu indeks yang membandingkan pangsa sub wilayah dalam aktivitas tertentu dengan pangsa total aktivitas dalam aktivitas total wilayah. Asumsi yang digunakan dalam analisis LQ adalah (1) kondisi geografis relatif seragam, (2) pola aktivitas bersifat seragam dan (3) setiap aktivitas menghasilkan produk yang seragam (Budiharsono, 2001).

Data yang digunakan adalah jumlah rumah tangga (tenaga kerja) yang berusaha menurut sektor ekonomi di wilayah desa/kelurahan di Kabupaten Mukomuko Tahun 2005 yang diperoleh dari Profil Desa/Kelurahan, yang berjumlah 85 desa/kelurahan. Penentuan produk andalan diperoleh dengan menggunakan persamaan $L Q$, dimana variabel-variabel yang digunakan adalah:

1. Jumlah pelaku ekonomi subsektor tanaman pangan

2. Jumlah pelaku ekonomi subsektor perkebunan

3. Jumlah pelaku ekonomi subsektor peternakan

4. Jumlah pelaku ekonomi subsektor perikanan/kenelayanan.

Nilai LQ diketahui dengan humus :

$$
L Q i j=\left[\frac{X i j / X i}{X j / X}\right]
$$


dimana: $\quad$ LQij = nilai LQ untuk aktivitas ke-j di wilayah ke-i

Xij = jumlah aktivitas ke-j di wilayah ke-i

$\mathrm{Xi} \quad=$ Total aktivitas di wilayah ke-i

$\mathrm{Xj} \quad=$ Total aktivitas ke-j di semua wilayah

$\mathrm{X}=$ Total semua aktivitas di semua wilayah

$\mathrm{i} \quad=$ Wilayah desa/kelurahan yang dikaji

$\mathrm{j} \quad=$ Aktivitas ekonomi yang dikaji

Berdasarkan hasil analisis $L Q$, interpretasi dilakukan dengan kriteria :

a. Jika nilai $L Q>1$, maka terjadi konsentrasi (pemusatan) suatu aktivitas relatif dibandingkan dengan total wilayah.

b. Jika nilai $L Q=1$, maka wilayah desa/kelurahan ke-i mempunyai pangsa aktivitas setara dengan pangsa total

c. Jika nilai $L Q<1$, maka wilayah ke-i memiliki pangsa relatif lebih kecil dibandingkan dengan aktivitas yang secara umum ditentukan di seluruh wilayah.

\section{Analisis Kelayakan Usaha.}

Untuk melihat kelayakan usaha dari suatu rencana pengembangan komoditi unggulan perlu dipertimbangkan aspek keuangan/finansil. Dalam aspek keuangan banyak alat analisis yang dapat digunakan seperti Payback Period (PP), Net Present Value (NPV), Benefit-Cost ratio (B/C), rata-rata keuntungan akuntansi, Internal Rate of Return (IRR) dan lain-lain.

Kelayakan usaha yang dimiliki oleh masyarakat dikaji dengan analisis kelayakan finansial, yang mencakup semua biaya dan manfaat yang timbul dari aktivitas ekonomi yang dilakukan oleh masyarakat. Teknik untuk mencari adanya putusan alokasi sumberdaya secara efisien adalah Cost Benefit Analysis dengan kriteria keputusan Net Present Value (NPV) dan B-C Ratio.

Alat analisis finansial yang digunakan dalam pemetaan produk andalan di Kabupaten Mukomuko adalah Net Present Value (NPV) dan Benefit-Cost Ratio. Net Present Value (NPV) digunakan untuk melihat seberapa besar keuntungan dari suatu proyek investasi.

Kelayakan usaha yang dimiliki oleh masyarakat dikaji dengan analisis kelayakan finansial, yang mencakup semua biaya dan manfaat yang timbul dari aktivitas ekonomi yang dilakukan oleh masyarakat. Teknik untuk mencari adanya putusan alokasi sumberdaya secara efisien adalah Cost Benefit Analysis dengan kriteria keputusan Net Present Value (NPV) dan B-C Ratio (Kusumastanto, 2000) .

Pengukuran cost-benefit analysis untuk penerapannya dalam analisis finansial, secara sederhana dapat digambarkan dalam formulasi berikut ini: 


$$
\begin{array}{ll}
N P V=\sum_{t=1}^{n} \frac{B t-C t}{(1+r)^{t}} \quad \text { dengan kriteria : } & \text { NPV } \geq 0 \text { : Usaha Layak } \\
\text { NPV }<0: \text { Usaha Tidak Layak }
\end{array}
$$

Analisis kelayakan usaha dilakukan untuk produk-produk andalan tertentu dari hasil sampling, berdasarkan karakteristik usaha yang dilakukan masyarakat. Produk-produk yang dianalisis secara finansial antara lain padi, jagung, kelapa sawit, perikanan laut.

Sedangkan selain empat komoditi di atas, tidak dapat dilakukan analisis finansial karena :

1. Karet, umumnya karet yang disadap oleh masyarakat adalah karet alam yang tidak diusahakan/dipelihara layaknya perkebunan karet. Tim mengalami kesulitan untuk membangun data-data keuangan yang dikeluarkan oleh masyarakat untuk investasi dan pemeliharaan. Bahkan ada kecenderungan, bahwa karet yang disadap masyarakat merupakan usaha (kebun) warisan atau pemberian dari orang tua.

2. Peternakan, dimana usaha ini merupakan usaha sampingan masyarakat yang lebih bersifat subsisten. Transaksi jual beli untuk ternak-ternak tertentu bersifat temporer yang tidak memiliki jangka waktu.

3. Perikanan Darat. Usaha ini berbentuk kolam ikan yang diusahakan diperkebunan kelapa sawit. Usaha ini juga bersifat subsisten, dimana panen ikan dilakukan berdasarkan keinginan pemiliknya.

\section{HASIL DAN PEMBAHASAN}

\section{Pemetaan Produk Andalan Sektor Pertanian}

\section{Subsektor Tanaman Pangan}

Aktivitas ekonomi subsektor tanaman pangan diklasifikasikan menjadi 5 kelompok, yaitu pemilik petani sawah, pemilik tanah tegalan/ladang, penyewa/penggarap, penyakap dan buruh tani. Jumlah total tenaga kerja yang beraktivitas pada seb sektor tanaman pangan sebanyak 
32.116 orang yang tersebar 85 desa/kelurahan pada lima kecamatan di Kabupaten Mukomuko. Dari jumlah tersebut, subsektor tanaman pangan menjadi andalan (basis ekonomi) pada :

a. Kecamatan Lubuk Pinang, sebanyak 12 desa (sekitar $75 \%$ dari total jumlah desa (16 desa) di Kecamatan Lubuk Pinang) yang terdiri dari 5.115 orang

b. Kecamatan Teras Terunjam, sebanyak 7 desa (sekitar $46,7 \%$ dari total jumlah desa (15 desa) di Kecamatan Teras Terunjam) yang terdiri dari 4.789 orang

c. Kecamatan Mukomuko Utara, sebanyak 5 desa (sekitar $31,25 \%$ dari total jumlah desa (16 desa/kelurahan) di Kecamatan Mukomuko Utara) yang terdiri dari 2.059 orang

d. Kecamatan Mukomuko Selatan, sebanyak 14 desa (sekitar 56\% dari total jumlah desa (25 desa) di Kecamatan Mukomuko Selatan) yang terdiri dari 4.148 orang

e. Kecamatan Pondok Suguh, sebanyak 9 desa (sekitar $69,23 \%$ dari total jumlah desa (13 desa) di Kecamatan Pondok Suguh) yang terdiri dari 4.947 orang

Ini berarti, subsektor tanaman pangan menjadi basis aktivitas ekonomi pada 47 desa/kelurahan atau sekitar 55,29\% dari total jumlah desa/kelurahan, dengan jumlah tenaga kerja sebanyak 21.058 orang atau sekitar $65,57 \%$ dari total tenaga kerja subsektor tanaman pangan di Kabupaten Mukomuko.

Subsektor tanaman pangan menjadi basis di Kecamatan Lubuk Pinang, Teras Terunjam dan Pondok Suguh. Luas lahan yang diusahakan masyarakat untuk menanam komoditi tanaman pangan (mayoritas padi dan jagung) adalah 32.356,45 Ha, yang terdiri dari 19.221,05 Ha lahan sawah dan 13.135,4 Ha ladang/tegalan. Lahan sawah diklasifikasikan menjadi 4 kategori, yaitu:

a. Sawah irigasi teknis, seluas $4.945 \mathrm{Ha}$

b. Sawah irigasi semi teknis, seluas $2.545,5 \mathrm{Ha}$

c. Sawah tadah hujan, seluas $7.919,3 \mathrm{Ha}$

d. Sawah pasang surut, seluas $3.811,25$

Pemilik tanah sawah di Kabupaten Mukomuko sebanyak 13.608 orang dan pemilik ladang/tegalan sebanyak 13.892 orang. Ini berarti, setiap petani memiliki lahan sawah seluas 1,38 $\mathrm{Ha}$ dan atau tegalan/ladang seluas $0,95 \mathrm{Ha}$.

\section{Subsektor Perkebunan}

Pekerjaan masyarakat pada subsektor tanaman perkebunan dibedakan menjadi dua kelompok, yaitu pemilik dan buruh perkebunan. Di Kabupaten Mukomuko, jumlah tenaga kerja yang bekerja pada subsektor ini sebanyak 36.862 orang. Dari jumlah tersebut, subsektor tanaman perkebunan menjadi andalan pada : 
a. Kecamatan Lubuk Pinang, sebanyak 8 desa (sekitar 50\% dari total jumlah desa di Kecamatan Lubuk Pinang) yang terdiri dari 5.964 orang

b. Kecamatan Teras Terunjam, sebanyak 8 desa (sekitar 53,33\% dari total jumlah desa di Kecamatan Teras Terunjam) yang terdiri dari 5.788 orang

c. Kecamatan Mukomuko Utara, sebanyak 8 desa (sekitar $50 \%$ dari total jumlah desa di Kecamatan Mukomuko Utara) yang terdiri dari 4.806 orang

d. Kecamatan Mukomuko Selatan, sebanyak 13 desa (sekitar $52 \%$ dari total jumlah desa di Kecamatan Mukomuko Selatan) yang terdiri dari 5.007 orang

e. Kecamatan Pondok Suguh, sebanyak 7 desa (sekitar $53,85 \%$ dari total jumlah desa di Kecamatan Pondok Suguh) yang terdiri dari 4.789 orang

Ini berarti, subsektor perkebunan menjadi basis aktivitas ekonomi pada 44 desa/kelurahan atau sekitar $51,76 \%$ dari total jumlah desa/kelurahan, dengan jumlah tenaga kerja sebanyak 26.354 orang atau sekitar $71,49 \%$ dari total tenaga kerja subsektor perkebunan di Kabupaten Mukomuko. Data ini menunjukkan bahwa jumlah masyarakat yang bekerja pada subsektor perkebunan lebih banyak jika dibandingkan dengan jumlah masyarakat yang bekerja pada subsektor tanaman pangan.

Subsektor perkebunan menjadi basis pada semua Kecamatan di Kabupaten Mukomuko. Perkebunan rakyat di Kabupaten Mukomuko seluas 45.558 Ha dengan jumlah pemilik sebanyak 29,385 orang. Ini berarti, setiap petani kebun memiliki lahan perkebunan seluas 1,55 Ha. Komoditas perkebunan yang paling banyak diusahakan masyarakat adalah kelapa sawit seluas $24.989 \mathrm{Ha}$, karet seluas 13.325 Ha dan kelapa seluas 1.772,7 Ha. Sisanya terdiri dari kelapa, kopi, kapuk, pinang, kapas, cengkeh, kemiri, jambu mete, vanili, lada, kakao, karet dan kayu manis.

\section{Subsektor Peternakan}

Jumlah tenaga kerja subsektor peternakan di Kabupaten Mukomuko sebanyak 28.230 orang dengan jenis ternak yang diusahakan adalah sapi, kambing, ayam, kerbau, babi, itik, domba dan buruh ternak. Tidak ada masyarakat yang beternak kuda.

Subsektor peternakan menjadi andalan pada :

a. Kecamatan Lubuk Pinang, sebanyak 6 desa (sekitar 37,5\% dari total jumlah desa di Kecamatan Lubuk Pinang) yang terdiri dari 3.639 orang

b. Kecamatan Teras Terunjam, sebanyak 8 desa (sekitar 53,33\% dari total jumlah desa di Kecamatan Teras Terunjam) yang terdiri dari 4.920 orang 
c. Kecamatan Mukomuko Utara, sebanyak 7 desa (sekitar $43,75 \%$ dari total jumlah desa di Kecamatan Mukomuko Utara) yang terdiri dari 5.106 orang

d. Kecamatan Mukomuko Selatan, sebanyak 10 desa (sekitar $40 \%$ dari total jumlah desa di Kecamatan Mukomuko Selatan) yang terdiri dari 3.688 orang

e. Kecamatan Pondok Suguh, sebanyak 5 desa (sekitar $38,46 \%$ dari total jumlah desa di Kecamatan Pondok Suguh) yang terdiri dari 2.074 orang

Subsektor peternakan menjadi basis aktivitas ekonomi masyarakat pada 36 desa/kelurahan (42,35\% dari jumlah desa/kelurahan) dengan jumlah tenaga kerja sebanyak 19.427 orang atau sekitar $68,82 \%$ dari tenaga kerja subsektor peternakan di Kabupaten Mukomuko. Subsektor peternakan menjadi basis di Kecamatan Lubuk Pinang, Mukomuko Utara dan Mukomuko Selatan.

\section{Subsektor Perikanan/Kenelayanan.}

Aktivitas subsektor perikanan/kenelayanan terdiri dari perikanan laut dan perikanan darat, dimana tenaga kerja dapat dikelompokkan berdasarkan kepemilikan kapal, perahu/sampan, usaha rumput laut, kolam, tambak dan buruh perikanan/kenelayanan. Jumlah tenaga kerja pada subsektor ini sebanyak 2.669 orang.

Subsektor perikanan/kenelayanan menjadi basis di Kecamatan Mukomuko Utara, Mukomuko Selatan dan Pondok Suguh. Subsektor perikanan/kenelayanan menjadi basis aktivitas ekonomi hanya pada 18 desa/kelurahan (21,18\% dari jumlah desa/kelurahan) dengan jumlah tenaga kerja sebanyak 2.349 orang atau sekitar $88,01 \%$ dari jumlah tenaga kerja subsektor perikanan/kenelayanan.

Rinciannya adalah :

a. Kecamatan Lubuk Pinang, sebanyak 1 desa (sekitar 6,25\% dari total jumlah desa di Kecamatan Lubuk Pinang) yang terdiri dari 21 orang

b. Kecamatan Teras Terunjam, sebanyak 2 desa (sekitar 13,33\% dari total jumlah desa di Kecamatan Teras Terunjam) yang terdiri dari 125 orang

c. Kecamatan Mukomuko Utara, sebanyak 3 desa (sekitar $18,75 \%$ dari total jumlah desa di Kecamatan Mukomuko Utara) yang terdiri dari 675 orang

d. Kecamatan Mukomuko Selatan, sebanyak 9 desa (sekitar $36 \%$ dari total jumlah desa di Kecamatan Mukomuko Selatan) yang terdiri dari 763 orang

e. Kecamatan Pondok Suguh, sebanyak 3 desa (sekitar $23,08 \%$ dari total jumlah desa di Kecamatan Pondok Suguh) yang terdiri dari 764 orang. 


\section{Kelayakan Finansial Produk Andalan}

Pada tahap kegiatan operasi, beberapa pertimbangan yang perlu menjadi perhatian adalah dalam berusaha adalah jumlah output, bagaimana output diproses, menyediakan fasilitas/sarana pendukung, pengamanan pada waktu pemrosesan, dan lain-lain. Masing-masing bidang usaha/produk mempunyai karakteristik dan perlakuan yang berbeda, sehingga memerlukan penanganan khusus baik dari segi input maupun kebutuhan keahlian tenaga kerja yang diperlukan. Dari berbagai komoditi unggulan, dilihat dari aspek teknis/operasi pengembangan komoditi tersebut dapat dilakukan secara baik dan tidak mengalami kendala yang berarti.

Berdasarkan hasil observasi dan identifikasi peluang usaha atau produk yang dapat dikembangkan di Kabupaten Mukomuko ternyata cukup banyak sektor usaha atau komoditi yang dapat dikembangkan. Namun jika dilihat dari segi aspek teknis/operasi ada beberapa pertimbangan yang perlu menjadi perhatian, karena masing-masing sektor atau usaha memerlukan spesifikasi teknis tertentu, mulai dari penyediaan bahan baku, proses produksi maupun pemasaran hasil-hasil produksi.

Dari berbagai rencana pengembangan komoditi unggulan yang ada, setelah dihitung secara finansial, terdapat beberapa produk yang NPV dan B/C cukup tinggi. Dari aspek finansil beberapa komoditi yang dianalisis dari segi NPV dan B/C hampir semuanya layak namun besar kecilnya keuntungan sangat bervariasi antara satu komoditi/usaha dengan yang lainnya karena perbedaan perbandingan antara besarnya investasi dengan hasil produksi dan umur ekonomis proyek.

\section{Kelayakan Finansial Komoditi Padi}

Komoditi padi yang diusahakan masyarakat dapat dikelompokkan menjadi padi sawah dan padi ladang. Pada sawah umumnya diusahakan petani dengan memanfaatkan saluran irigasi teknis. Secara rata-rata produksi padi sawah sekitar 3,09 ton per hektar per musim tanam (MT). Dengan harga jual rata-rata gabah kering sebesar Rp 1.800/kg, maka diperoleh nilai NPV yang postif. Nilai B/C sebesar 2,92, yang berarti setiap biaya yang dikeluarkan oleh petani sebesar satu rupiah, memberikan pendapatan sebesar 2,92 rupiah. Nilai NPV dan B/C ini meunjukkan usaha padi sawah yang dilakukan oleh petani dapat dinyatakan layak secara finansial.

Padi ladang yang diusahakan oleh petani memiliki produktivitas yang lebih rendah dibandingkan dengan padi sawah, dimana rata-rata produksi hanya sekitar 1,63 ton/ha/MT. Dengan harga gabah rata-rata Rp 1.800/kg, maka diperoleh nilai NPV yang positif dan nilai B/C sebesar 1,54. Dengan demikian, usaha padi ladang juga dapat dinyatakan layak secara finansial. 
Perhitungan analisis finansial padi sawah dan padi ladang dilakukan dengan menggunakan biaya dan pendapatan per satu hektar. Sehingga meskipun dalam perhitungan padi sawah dan padi ladang layak secara finansial, pada kenyataannya pendapatan petani masih dalam kategori rendah. Hal ini disebabkan oleh lahan yang diusahakan petani masih kecil, dimana luas lahan yang diusahakan mayoritas petani antara $0,25 \mathrm{Ha}-0,75 \mathrm{Ha}$.

Hasil analisa memberikan alternatif peningkatan pendapatan petani padi melalui 2 cara yaitu:

a. Peningkatan produktivitas

Demplot/percontohan penanaman padi sawah yang dilakukan oleh Dinas Pertanian Kabupaten Mukomuko pada Tahun 2006 memberikan hasil produksi mencapai 9 ton/Ha/MT (Dinas PPKP Kabupaten Mukomuko, 2006). Dengan produktivitas rata-rata petani yang hanya 3,09 ton/Ha/MT, terbuka peluang yang sangat besar untuk meningkatkan hasil produksi padi.

b. Penggabungan lahan petani

Pengusahaan lahan petani yang relatif kecil memberikan dampak inefisiensi dalam pemanfaatan modal, yang terdiri dari investasi, biaya tetap dan biaya variabel. Penerapan pola corporate farming menjadi salah satu alternatif dalam peningkatan efisiensi usaha. Corporate farming dilakukan dengan menggabungkan lahan petani yang kecil-kecil menjadi dalam satu manajemen (pengusahaan) dengan terlebih dahulu memilih salah satu petani (investor) yang sanggup mengusahakan lahan yang telah digabung. Distribusi pendapatan dapat diterapkan dengan pola bagi hasil.

\section{Kelayakan Finansial Komoditi Jagung}

Produksi rata-rata jagung sekitar 3,26 ton/Ha/MT. Ini berarti, hasil produksi jagung lebih besar dari produksi padi sawah dan padi jagung. Dengan rata-rata harga jual jagung sebesar Rp $1.250 / \mathrm{kg}$, maka diperoleh nilai NPV yang positif dan nilai $B / C$ sebesar 1,94 . Nilai $B / C$ ini mengindikasikan bahwa setiap 1 rupiah biaya yang dikeluarkan oleh petani jagung akan memperoleh pendapatan sebesar $\mathrm{Rp} 1,94$.

Komoditi jagung yang diusahakan oleh petani dapat dinyatakan layak secara finansial. Sama halnya dengan petani padi, pengusahaan lahan oleh petani juga relatif kecil-kecil sehingga pada kenyataannya, pendapatan petani jagung juga masih rendah. Dengan demikian, pola corporate farming juga dapat diterapkan pada usaha jagung. 


\section{Kelayakan Usaha Komoditi Kelapa Sawit}

Sektor usaha yang berupa perkebunan, aspek teknis/operasi berkaitan dengan penyediaan lahan, pembangunan gudang, pembangunan jalan, kantor dan lain sebagainya dapat dilakukan mengingat ketersediaan lahan maupun tenaga kerja dalam jumlah yang memadai.

Umumnya, usaha perkebunan kelapa sawit masyarakat dapat dinyatakan layak secara finansial. Hal ini terkait dengan pengusahaan lahan kebun kelapa sawit masyarakat lebih besar, dimana rata-rata masyarakat memiliki kebun lebih dari 1 hektar.

Dengan menggunakan umur ekonomis kelapa sawit selama 25 tahun, diperoleh nilai NPV yang positif dan B-C ratio sebesar 1,24. Ini berarti, setiap 1 rupiah yang diinvestasikan petani, memberikan pendapatan sebesar 1,24 rupiah. Usaha perkebunan kelapa sawit dapat dinyatakan layak secara finansial.

\section{Kelayakan Usaha Perikanan Laut}

Pada subsektor usaha perikanan, diperlukan sarana pendukung seperti kapal dan alat penangkapan dengan mendatangkan alat-alat tangkap dan mesin dari luar daerah. Oleh karena itu dibutuhkan pengetahuan tentang: jenis-jenis mesin yang tersedia dan perlengkapan lainnya, seperti ukuran mesin, spesifikasi teknis mesin, bahan bakar/energi yang diperlukan, maupun dalam hal pemeliharaan peralatan. Melihat kondisi saat ini semua peralatan yang diperlukan maupun pengoperasian peralatan dapat dilakukan dengan baik karena sebagian para nelayan sudah menggunakan alat tangkap semi modern.

Peralatan usaha melaut berbeda-beda antara satu nelayan dengan nelayan yang lainnya, dan sangat variatif. Ada nelayan yang hanya memiliki alat tangkap saja, sehingga ketika melaut harus menumpang dengan orang lain. Namun ada pula nelayan yang memiliki peralatan yang lengkap, seperti alat tangkap, kapal, motor, dan ice box (sehingga ikan dapat disimpan lebih lama dan tidak cepat membusuk).

Namun secara rata-rata, produksi ikan (hasil tangkapan) nelayan sekitar $75 \mathrm{~kg} / \mathrm{trip}$ dan rata-rata harga jual Rp 6.000/kg maka diperoleh nilai NPV yang positif dan B-C ratio sebesar 1,25. Usaha nelayan dinyatakan layak secara finansial.

Umumnya, usaha nelayan di Kabupaten Mukomuko bersifat one day fishing, dimana nelayan pergi melaut pada dini hari dan pulang pada siang harinya. Ada juga nelayan yang melaut selama 2-4 hari, namun jumlahnya tidak sebanyak nelayan one day fishing. Ini menandakan terjadinya ketimpangan dalam kepemilikan alat tangkap sehingga rawan pula terhadap masalahmasalah sosial. Dengan demikian, diharapkan program-program pemerintah (baik pusat maupun 
daerah) yang ada di Kabupaten Mukomuko lebih fokus pada memperkecil ketimpangan kepemilikan alat tangkap.

\section{KESIMPULAN}

Berdasarkan hasil kajian seperti yang telah dibahas di atas, maka dapat dirumuskan kesimpulan antara lain :

1. Subsektor tanaman pangan menjadi basis di tiga kecamatan (Lubuk Pinang, Teras Terunjam dan Pondok Suguh), sebsektor peternakan menjadi basis di tiga kecamatan (Lubuk Pinang, Mukomuko Utara dan Mukomuko Selatan), subsektor perikanan/kenelayanan menjadi basis pada tiga kecamatan (Mukomuko Utara, Mukomuko Selatan dan Pondok Suguh) dan subsektor perkebunan menjadi basis pada semua wilayah kecamatan.

2. Secara finansial, usaha masyarakat yang menanam jagung, padi, kelapa sawit dan mencari ikan di laut (perikanan laut) dapat dinyatakan layak. Namun, pengusahaan semua jenis usaha (selain kelapa sawit) dilakukan dalam skala kecil sehingga pendapatan yang diperoleh belum mampu memenuhi kebutuhan konsumsi rumah tangga.

\section{DAFTAR PUSTAKA}

Bappeda Kabupaten Mukomuko, 2007. Profil Daerah Kabupaten Mukomuko. Mukomuko , 2005. Profil Desa Kabupaten Mukomuko. Mukomuko. , 2005. Rencana Pembangunan Jangka Menengah (RPJM) Kabupaten Mukomuko. Mukomuko.

Budiharsono, Sugeng, 2001. Teknik Analisis Pembangunan Wilayah Pesisir dan Lautan. PT Pradnya Paramita. Jakarta.

Dinas Kehutanan dan Perkebunan Kabupaten Mukomuko, 2006. Profil Kehutanan dan Pertanian Kabupaten Mukomuko Tahun 2006. Mukomuko.

Dinas PPKP Kabupaten Mukomuko, 2006. Profil Pertanian Kabupaten Mukomuko Tahun 2006. Mukomuko.

Kusumastanto, T. 2000. Ekonomi Sumberdaya dan Lingkungan. Diktat Kuliah PS SPL - IPB. Bogor.

Nazir, Moh. 1999. Metode Penelitian. Cetakan Keempat. Penerbit Ghalia Indonesia. 